\title{
Concentrations of Trace Metals in Selected Land Uses of a Dry Zone Soil Catena of Sri Lanka
}

\author{
F. Rosemary ${ }^{*}$, U.W.A. Vitharana ${ }^{1}$, S.P. Indraratne ${ }^{1}$ and S.V.R.Weerasooriya ${ }^{1}$ \\ Postgraduate Institute of Agriculture \\ University of Peradeniya \\ Sri Lanka
}

\begin{abstract}
Assessment of environmental risk associated with the pollution of trace metals is important for proper management of soils. This study was conducted to find out the present level of trace metals, their sources and the relationships among them in selected land uses. A Dry Zone soil catena consisting of uncultivated, paddy-cultivated and vegetablecultivated land uses was selected for this study. A total of 58 soil samples were collected on the basis of latin hypercube sampling approach. Soil samples were analyzed for the total concentrations of $\mathrm{Cd}, \mathrm{Cu}, \mathrm{Pb}, \mathrm{Ni}$ and $\mathrm{Zn}$. Exploratory data analysis, correlation analysis, mean comparison test and principal component analysis (PCA) were performed for the data. All the trace metals analyzed were below the maximum permissible levels in the soil catena studied. An accumulation of Cd was observed in paddy lands. The PCA confirmed the contribution of anthropogenic factors on Cd levels observed in this Dry Zone soil catena. Copper and Ni concentrations did not vary among the selected land uses while $\mathrm{Zn}, \mathrm{Cd}$ and $\mathrm{Pb}$ concentrations varied with land uses. A strong and a significant relationship between $\mathrm{Cu}$ and $\mathrm{Zn}$ in all three land uses indicated a common origin of these metals. The PCA indicated that $\mathrm{Cu}, \mathrm{Zn}$ and $\mathrm{Pb}$ would have originated from the mixed factor of natural and anthropogenic sources. The PCA also indicated the natural origin of Ni in the tested soils.
\end{abstract}

Keywords: Paddy lands, PCA, trace metals concentrations, uncultivated lands, vegetable lands

\section{INTRODUCTION}

In present day agriculture, excessive application of inputs, such as fertilizers and pesticides are common practices. Some of these agrochemicals contain trace metals as an active ingredient (Rezania et al., 1989). Excessive addition of such agrochemicals could lead to the contamination of agricultural soils. Elevated trace metal concentrations could cause phytotoxic effects and also could result in the trace metals contamination in edible crops (Cobb et al., 2000). Soil ingestion and consumption of contaminated food are major pathways where human can be exposed to toxic trace metals. Accumulation of trace metals in the human body can cause diseases in the digestive system, anemia and chronic renal failure (Wanigasuriya et al., 2008; Chandrajith et al., 2010), etc. Therefore, public attention on soil contaminants has increased considerably in recent years.

Trace metals enter the soils from natural and anthropogenic sources. Burt et al., (2003) reported that the quantity of trace metals that enter the ecosystem from anthropogenic sources is considerably higher than that of the natural sources. Anthropogenic sources, such

\footnotetext{
1 Department of Soil Science, Faculty of Agriculture, University of Peradeniya, Sri Lanka

* Corresponding author: rosemary.fernando@gmail.com
} 
as chemical fertilizers, especially Triple Super Phosphate (TSP) contain considerable level of Cd as impurities (Pierzynski et al., 2000) and Wijewardena \& Gunarathne (2004) reported that animal manure also contain some amount of trace metals. Excessive application of such chemical and animal fertilizers could lead to an accumulation of trace metals in agricultural fields. Premarathne et al. (2011) reported elevated levels of trace elements in soils of vegetable fields of some parts in Sri Lanka. Premarathna et al. (2005) also observed that the total soil Cd concentration of $3.85 \mathrm{mg} \mathrm{kg}^{-1}$ in vegetable growing soils in the upcountry wet zone of Sri Lanka. Previous studies by Bandara et al. (2008) showed $1.78-2.45 \mathrm{mg} \mathrm{kg}^{-1}$ of $\mathrm{Cd}$ content in sediments collected from some reservoirs in the dry zone. However, there are only a few studies carried out in addressing the present level of trace metals content in soils of the dry zone of Sri Lanka.

The solubility, mobility and bioavailability of trace metals in soils depend on their chemical species which are controlled by soil characteristics, such as $\mathrm{pH}$, organic matter, clay content and secondary minerals (He et al., 2004). Therefore, the type of soils play a major role in the accumulation and persistence of soil trace metals. Further, land uses and management practices can affect the dynamics of trace metals concentrations in soils. Lu (2007) observed that $\mathrm{As}, \mathrm{Cd}$ and $\mathrm{Cr}$ concentrations were greater in arable lands whereas in orchard lands, concentrations of $\mathrm{Cu}$ and $\mathrm{Pb}$ were high. Therefore, it is necessary to characterize trace metals in relation to different land uses to predict their behavior in soils.

Understanding the present level of concentration of trace metals in soils is necessary to detect trends of contamination of soils. Nevertheless, the implementation of mitigation strategies to minimize the exposure of trace metals to human, to reduce concentration in soil solution, to minimize food chain contamination and to reduce environmental risk for natural ecosystem are entirely dependent on the thorough understanding on the present level of heavy metal contaminations of soils. This study was conducted (i) to compare the concentrations of trace metals in different land uses (ii) to develop the relationship between trace metal concentrations and land uses (iii) to predict the sources of trace metal concentrations in a dry zone soil catena.

\section{METHODOLOGY}

\section{Site description}

A soil catena situated in Medawachchiya - Ranorawa - Elayapattuwa - Hurathgama Nawagaththegama association (Mapa, 2010), in the dry zone of Sri Lanka was selected for this study. The selected catena covers an area of 94 ha and dominated with Ranorawa (in uplands) and Elayapattuwa (in lowlands) soil series. The central coordinates are $8^{\circ} 7^{\prime} 57.07^{\prime \prime}$ $\mathrm{N}$ and $80^{\circ} 7,51.22^{\prime}$ E and the average elevation is approximately $65 \mathrm{~m}$ from the sea level. Rainfall pattern is bimodal, consists of south west and north east monsoon rains, demarcating two major growing seasons namely, Yala and Maha seasons, respectively. Annual rainfall of the area is less than $1750 \mathrm{~mm}$. Rainfed crop cultivation is practiced in Maha season and Yala season cultivation is practiced using the irrigation water from the Rajanganaya reservoir. Major soil great groups of the area are Typic Rhodustalfs and Oxyaquic Paleudalfs (USDA soil taxonomy). Major land uses of the area are uncultivated lands and agricultural land uses, namely rice fields and vegetable cultivations. Some of the uncultivated areas were previously cultivated but abandoned for more than two years. The selected catena is gently sloping towards the northern direction and paddy lands are mainly distributed at the northern part of 
the catena whereas vegetable and uncultivated lands are situated at the southern part of the catena.

\section{Sampling method}

Latin hypercube sampling technique (Budiman, 2006) was used to identify sample locations representing the spatial distribution of present land uses. Sampling was done at the end of April, 2012 and at each location, three samples were collected at the depth of 0-30 cm using a gouge auger then mixed to obtain a composite soil sample. Total of 58 samples were collected from paddy (27 samples), vegetable (16 samples) and uncultivated (15 samples) lands. All the sampling points were geo-referenced using GPS receiver (Garmin GPS etrex10). Soil samples collected were air dried on clean polythene sheets, crushed and sieved using $2 \mathrm{~mm}$ sieve. Soil samples were stored in sealed transparent polythene bags, until analysis.

\section{Laboratory analysis}

Total trace metal concentrations were determined as the method described by Sposito et al. (1983), where $2 \mathrm{~g}$ of air dried soil sample was digested with $20 \mathrm{ml}$ of $4 \mathrm{M} \mathrm{HNO}_{3}$ in a water bath at $80{ }^{\circ} \mathrm{C}$ for 4 hours. Xing \&Veneman (1998) recommended the use of nitric acid in place of hydrofluoric acid since it can be conveniently used as an extractant to solubilize metals from soils and from plant materials for environmental monitoring. Finally, the extracted soil sampleswere filtered using Whatman no 42 filter paper and total concentrations of cadmium $(\mathrm{Cd})$, copper $(\mathrm{Cu})$, lead $(\mathrm{Pb})$, nickel $(\mathrm{Ni})$ and zinc $(\mathrm{Zn})$ of filtrates were measured using atomic absorption spectrophotometer. A Standard Reference Material (SRM) no 2586 from National Institute of Standards and Technology (NIST), USA, was digested along with the samples to assure the accuracy of measurements. Satisfactory recoveries were found for $\mathrm{Cd}(86.8 \%)$ and $\mathrm{Pb}(91.9 \%)$ in SRM. To assure the accuracy and precision of analysis, standard quality control practices were adopted during the analysis and blank samples were included in each batch of analysis.

\section{Data analysis}

Exploratory analysis was performed using SPSS statistical package (SPSS Inc, USA) for all trace metals. The data was tested for the normality with Kolmogorov - Smirnov (K-S) test. Mean concentrations of trace metals across land uses were compared using the mean comparison test. Pearson correlation (r) analysis was performed for trace metals to find out the relationship among trace metals in different land uses. In this study, principal component analysis (PCA) with varimax rotation method was used with Kaiser normalization to identify the sources of trace metals.

\section{RESULTS AND DISCUSSION}

According to the K-S normality test, all trace metals showed normal distributions. Skewness and kurtosis coefficient of each trace metals also indicated the normal distribution (Table 1). According to the European community set standards (McGrath \& McCormack, 1999), $3 \mathrm{mgkg}^{-1}$ of $\mathrm{Cd}$ is the upper limit of the maximum allowable concentration in soils. The $\mathrm{Cd}$ contents of few samples showed elevated levels closer to the lower limit of the maximum allowable concentration $\left(1 \mathrm{mg} \mathrm{kg}{ }^{-1}\right)$ specified in the European community set standards (McGrath \& McCormack, 1999). Moreover, all these samples were distributed in paddy and 
vegetable lands. Therefore, the use of agricultural inputs could be suspected as the reason for the enrichment of $\mathrm{Cd}$ concentrations in some parts of the catena. Indraratne et al. (2011) observed Cd concentrations, ranging from $0.003 \mathrm{mg} \mathrm{kg}^{-1}$ to $0.09 \mathrm{mg} \mathrm{kg}^{-1}$ in the sediments of some selected tank beds in Anuradhapura and Madirigiriya. The range of values observed in this catena was 0.01 to $0.65 \mathrm{mg} \mathrm{kg}^{-1}$. The estimated upper limit of the geochemical baseline concentration for $\mathrm{Cd}$ in Medawachchiya - Ranorawa - Elayapattuwa - Hurathgama Nawagaththegama map unit is $1.39 \mathrm{mg} \mathrm{kg}^{-1}$ (Sanjeevani et al., 2012). All the values observed in this catena were below this level. According to Ma et al. (1997) the estimated background concentrations of $\mathrm{Cd}$ in Florida soils is $0.21 \mathrm{mg} \mathrm{kg}^{-1}$, for world soils it is $0.37 \mathrm{mg}$ $\mathrm{kg}^{-1}$ (Kabata-Pendias et al., 1992). The Cd values obtained in this study were slightly higher than the values reported elsewhere. Differences could be due to the time frame of analysis, where in other places mentioned above determined their background concentrations about two decades ago.

The mean contents of $\mathrm{Cd}$ in paddy, vegetable and uncultivated lands were $0.35,0.28$ and $0.26 \mathrm{mg} \mathrm{kg}^{-1}$, respectively. The mean comparison indicated that $\mathrm{Cd}$ content in paddy lands is significantly higher $(\mathrm{p}=0.05)$ than that of the vegetable and uncultivated lands. Higher content of trace metals such as $\mathrm{Cd}, \mathrm{Pb}, \mathrm{V}, \mathrm{U}$ and $\mathrm{Cr}$ were found in phosphate fertilizers (Dissanayake \& Chandrajith, 2009). Further, Premarathna et al. (2011) reported TSP contains $23.5 \mathrm{mg} \mathrm{kg}{ }^{-1}$ of $\mathrm{Cd}$. The continuous use of $\mathrm{Cd}$ containing agrochemicals such as TSP could contribute to elevated levels of $\mathrm{Cd}$ in paddy lands. According to the information gathered from the farmers, most of the vegetable fields in the study area were not continuously cultivated whereas paddy lands were cultivated continuously. Further, Indraratne et al. (2011) found traces of $\mathrm{Cd}$ in irrigation water of Rajangana tank and its outlets. Therefore, the long-term use of irrigation water sourced from the Rajangana tank could also have contributed for the accumulation of $\mathrm{Cd}$ in paddy growing lands.

Table 1. Descriptive statistics of trace metals in different land uses in selected dry zone catena

\begin{tabular}{llccccrr}
\hline $\begin{array}{l}\text { Trace } \\
\text { element }\end{array}$ & Land uses & Min & Max & Mean $\pm \mathbf{S D}^{*}$ & $\mathbf{C V}^{\#} \%$ & $\begin{array}{r}\text { Skewe } \\
\text {-ness }\end{array}$ & $\begin{array}{r}\text { Kur- } \\
\text {-tosis }\end{array}$ \\
\hline $\mathrm{Cd}$ & Paddy & 0.01 & 0.63 & $0.35 \pm 0.16^{\mathrm{a}}$ & 45.71 & 0.09 & -0.60 \\
$\left(\mathrm{mg} \mathrm{kg}^{-1}\right)$ & Vegetable & 0.01 & 0.65 & $0.28 \pm 0.17^{\mathrm{b}}$ & 60.71 & -0.15 & -1.62 \\
& Uncultivated & 0.06 & 0.57 & $0.26 \pm 0.18^{\mathrm{b}}$ & 69.23 & 0.48 & -1.37 \\
$\mathrm{Cu}$ & Paddy & 0.82 & 4.50 & $2.43 \pm 0.85^{\mathrm{a}}$ & 34.97 & 0.39 & 0.59 \\
$\left(\mathrm{mg} \mathrm{kg}^{-1}\right)$ & Vegetable & 0.78 & 8.54 & $2.97 \pm 1.39^{\mathrm{a}}$ & 46.80 & 1.08 & 0.41 \\
& Uncultivated & 0.52 & 6.83 & $2.36 \pm 1.91^{\mathrm{a}}$ & 80.93 & 1.46 & 1.99 \\
$\mathrm{~Pb}$ & Paddy & 2.90 & 9.30 & $6.05 \pm 1.71^{\mathrm{c}}$ & 28.26 & 0.12 & -0.81 \\
$\left(\mathrm{mg} \mathrm{kg}^{-1}\right)$ & Vegetable & 3.29 & 10.35 & $7.75 \pm 2.36^{\mathrm{b}}$ & 30.45 & -0.86 & -0.68 \\
& Uncultivated & 7.19 & 9.69 & $8.63 \pm 0.73^{\mathrm{a}}$ & 8.45 & -0.74 & 0.13 \\
$\mathrm{Ni}$ & Paddy & 0.04 & 13.45 & $4.95 \pm 3.27^{\mathrm{a}}$ & 66.06 & 0.59 & 0.19 \\
$\left(\mathrm{mg} \mathrm{kg}^{-1}\right)$ & Vegetable & 3.26 & 15.27 & $7.22 \pm 4.32^{\mathrm{a}}$ & 59.83 & 0.95 & 0.15 \\
$\mathrm{Zn}$ & Uncultivated & 1.26 & 10.60 & $4.69 \pm 2.73^{\mathrm{a}}$ & 58.20 & 0.85 & 1.06 \\
$\left(\mathrm{mg} \mathrm{kg}^{-1}\right)$ & Paddy & 4.57 & 19.09 & $10.78 \pm 3.38^{\mathrm{b}}$ & 31.35 & 0.13 & 0.12 \\
& Vegetable & 5.49 & 23.37 & $13.59 \pm 5.20^{\mathrm{a}}$ & 38.26 & 0.31 & -0.49 \\
\hline "SD-Stab & Uncultivated & 9.33 & 19.52 & $14.48 \pm 3.92^{\mathrm{ab}}$ & 27.07 & -0.12 & -1.65 \\
\hline
\end{tabular}

SD-Standard deviation ${ }^{\#} \mathrm{CV}$ - Coefficient of variation

* Land uses followed by different letters are significantly different at the $\mathrm{p}<0.05$ level. 
Copper is a micro-nutrient required in small quantities. This is an important nutrient for root metabolism and for reproductive growth in plants. The maximum permissible limit imposed for $\mathrm{Cu}$ in soils by the European community set standards (McGrath \& McCormack, 1999) is 50 to $140 \mathrm{mg} \mathrm{kg}^{-1}$. The mean contents of the $\mathrm{Cu}$ in paddy, vegetable and uncultivated lands were below the maximum permissible level set by European community set standards for $\mathrm{Cu}$ in soils (Table 1). The mean contents of $\mathrm{Cu}$ in paddy, vegetable and uncultivated areas were not significantly different. Jayewardene et al. (2012) documented 25,23 and $57 \mathrm{mg} \mathrm{kg}^{-1}$ of $\mathrm{Cu}$ contents in soils of agricultural areas of Madirigiriya, Talawa and Padaviya, respectively. The observed values for $\mathrm{Cu}$ were far below the estimated upper limit of the geochemical baseline concentration for $\mathrm{Cu}\left(26.51 \mathrm{mg} \mathrm{kg}^{-1}\right)$ by Sanjeevani et al. (2012) for the Medawachchiya - Ranorawa - Elayapattuwa - Hurathgama - Nawagaththegama map unit. The critical value and the range of optimum level of $\mathrm{Cu}$ content for paddy soils are 0.5 and 1 to $3 \mathrm{mg} \mathrm{kg}^{-1}$ respectively (Bandara et al., 2005). Copper content in paddy soils ranged from 0.82 to $4.50 \mathrm{mg} \mathrm{kg}^{-1}$ (Table 1 ).

Lead can be considered as least mobile heavy metal in the soil, out of metals studied. It can accumulate in the topsoil because usually it is not leached (Davies, 1984). The Pb content in all the samples were far below the lower permissible limit identified in the European community set standards $\left(<50 \mathrm{mg} \mathrm{kg}^{-1}\right)$. The mean contents of $\mathrm{Pb}$ were significantly different in different land uses. The average $\mathrm{Pb}$ content in uncultivated soils was higher than cultivated soils. Jayewardena et al. (2012) observed 21, 28 and $32 \mathrm{mg} \mathrm{kg}^{-1}$ of Pb content in agricultural soils of Madirigiriya, Talawa and Padaviya areas, respectively. The values observed in this catena were below the upper limit of the geochemical baseline for $\mathrm{Pb}$ established for a dry zone map unit (Sanjeevani et al., 2012). The $\mathrm{Pb}$ content in upper continental crust is $17 \mathrm{mg} \mathrm{kg}^{-1}$ (Rudnick \& Gao, 2005). Cultivation did not show any enrichment of $\mathrm{Pb}$ in the study area, indicating non-agricultural sources, such as parent material and atmospheric deposition of $\mathrm{Pb}$.

Nickel is now considered as a micro and seventeenth plant nutrient (Liu, 2001) because it involves in translocation of nitrogen in plants. The optimum requirement of $\mathrm{Ni}$ for plants is less than $0.5 \mathrm{mg} \mathrm{kg}^{-1}$ of dry weight (Liu, 2011). The mean contents of the $\mathrm{Ni}$ in paddy, vegetable and uncultivated lands in this catena were $4.98,7.22$ and $4.69 \mathrm{mg} \mathrm{kg}^{-1}$ respectively, much less than the lower permissible limit $\left(30 \mathrm{mg} \mathrm{kg}^{-1}\right)$ for Ni (McGrath \& McCormack, 1999). No significant differences were observed among the different land uses in the $\mathrm{Ni}$ content. The established upper limit of the geochemical baseline concentration for $\mathrm{Ni}$ is 38.8 $\mathrm{mg} \mathrm{kg}^{-1}$ (Sanjeevani et al., 2012) which is higher than the values observed for this catena.

Zinc is a micro-nutrient which is needed for the transformation of carbohydrates, regulate plant growth and consumption of sugars. When comparing paddy and vegetable cultivated soils, vegetable cultivated soils showed a significantly higher $\mathrm{Zn}$ content than that of paddy soils. Zinc deficiency has been reported in some parts of the dry zone of Sri Lanka. The critical value and optimum levels of $\mathrm{Zn}$ in soils for paddy cultivation in Sri Lanka are $1 \mathrm{mg}$ $\mathrm{kg}^{-1}$ and 2 to $4 \mathrm{mg} \mathrm{kg}^{-1}$, respectively (Bandara et al., 2005). The $\mathrm{Zn}$ content observed in the studied paddy soils was higher than the critical level. However, the $\mathrm{Zn}$ content in all three land uses was below the maximum permissible level set for environment pollution (300 $\mathrm{mg}$ $\mathrm{kg}^{-1}$ ) (McGrath \& McCormack, 1999). The values of $\mathrm{Zn}$ in this area were less than the established upper limit of the geochemical baseline concentration of $51.25 \mathrm{mg} \mathrm{kg}^{-1}$ by Sanjeevani et al. (2012). 


\section{Correlations among trace metals and land uses}

Copper showed a strong $(\mathrm{r}=0.8, \mathrm{p}=0.01)$ (Table 2) correlation with $\mathrm{Zn}$ content in uncultivated soil, indicating that both are from the same origin. Strong relationship among trace metals explains the similar sources among them (Li et al., 2009). None of other trace metals in uncultivated soils showed any relationship with others. Lead showed a positive correlation $(\mathrm{r}=0.5, \mathrm{p}=0.01)$ with $\mathrm{Cu}$, and with $\mathrm{Ni}(\mathrm{r}=0.5 \mathrm{p}=0.05)$ in paddy soils (Table $3)$. Copper showed significantly positive correlations with $\mathrm{Zn}(\mathrm{r}=0.8 \mathrm{p}=0.01)$ and $\mathrm{Ni}(\mathrm{r}=$ $0.5, \mathrm{p}=0.01)$. Other trace metals in paddy lands did not show any relationship with other trace metals.

Table 2. Pearson correlation matrix of trace metals concentrations in uncultivated lands $(n=15)$

\begin{tabular}{lcccc}
\hline Parameters & $\mathbf{C d}$ & $\mathbf{C u}$ & $\mathbf{P b}$ & $\mathbf{N i}$ \\
\hline $\mathbf{P b}$ & 0.42 & -0.38 & & \\
$\mathbf{N i}$ & 0.06 & 0.49 & -0.41 & \\
$\mathbf{Z n}$ & 0.10 & $0.81^{* *}$ & -0.37 & 0.18 \\
\hline
\end{tabular}

** Correlation is significant at the 0.01 probability level.

In vegetable cultivated soils, a strong and a positive correlation was observed between $\mathrm{Cu}$ and $\mathrm{Ni}(\mathrm{r}=0.8)$ at 0.01 probability level (Table 4). Zinc concentration showed positive correlations with $\mathrm{Cu}(\mathrm{r}=0.6)$ and also with $\mathrm{Ni}(\mathrm{r}=0.5)$ at the 0.05 probability level.

Table 3. Pearson's correlation matrix of trace metals concentrations in paddy $(n=27)$ cultivated soils

\begin{tabular}{lcccc}
\hline Parameters & $\mathbf{C d}$ & $\mathbf{C u}$ & $\mathbf{P b}$ & $\mathbf{N i}$ \\
\hline $\mathbf{C u}$ & 0.02 & & & \\
$\mathbf{P b}$ & 0.11 & $0.49^{* *}$ & & \\
$\mathbf{N i}$ & 0.08 & $0.54^{* *}$ & $0.46^{*}$ & \\
$\mathbf{Z n}$ & -0.11 & $0.75^{* *}$ & 0.35 & 0.38 \\
\hline
\end{tabular}

** Correlation is significant at the 0.01 level.

* Correlation is significant at the 0.05 level.

Table 4. Pearson's correlation matrix of trace metals concentrations in vegetable $(n=16)$ cultivated soils

\begin{tabular}{lcccc}
\hline Parameters & $\mathbf{C d}$ & $\mathbf{C u}$ & $\mathbf{P b}$ & $\mathbf{N i}$ \\
\hline $\mathbf{C u}$ & 0.42 & & & \\
$\mathbf{P b}$ & -0.10 & 0.25 & & \\
$\mathbf{N i}$ & 0.27 & $0.81^{* *}$ & 0.37 & \\
$\mathbf{Z n}$ & 0.13 & $0.56^{*}$ & 0.32 & $0.54^{*}$ \\
\hline
\end{tabular}

** Correlation is significant at the 0.01 level.

* Correlation is significant at the 0.05 level.

Copper showed strong positive relationship with $\mathrm{Zn}$ in all three land uses (Table 2, 3 and 4) indicating a common source for both elements. However, the correlation analysis alone is not sufficient itself to explain the sources of trace metals. 


\section{Probable sources of trace metals in the selected dry zone catena}

Principal component analysis can be used to identify the sources of trace metals as lithogenic, anthropogenic or mixed.

Table 5 shows the total variance explained by each component and component matrixes of trace metal contents. According to the PCA, trace metals could be grouped into two principal components which accounted for $61 \%$ of total variation. The loading plot for two rotated component is shown in Fig. 2. First component is accounted for $39.9 \%$ of the total variation which contributed greater positive factor loadings on $\mathrm{Zn}$ and $\mathrm{Cu}$ and a positive smaller factor loading on $\mathrm{Pb}$. Second component is accounted for $21 \%$ of the total variation which exhibited a positive factor loading on $\mathrm{Ni}$ and negative factor loading on $\mathrm{Cd}$.

Table 5. Total variance explained and component matrixes for trace metals content

\begin{tabular}{lcccccc}
\hline Component & \multicolumn{3}{c}{ Initial Eigen values } & \multicolumn{2}{c}{ Rotation Sums of Squared Loadings } \\
\hline & Total & $\begin{array}{c}\text { \% of } \\
\text { Variance }\end{array}$ & $\begin{array}{c}\text { Cumulative } \\
\%\end{array}$ & Total & $\begin{array}{c}\% \text { of } \\
\text { Variance }\end{array}$ & $\begin{array}{c}\text { Cumulative } \\
\%\end{array}$ \\
\hline 1 & 1.99 & 39.89 & 39.89 & 1.99 & 39.70 & 39.70 \\
2 & 1.07 & 21.53 & 61.43 & 1.09 & 21.73 & 61.43 \\
3 & 0.93 & 18.51 & 79.94 & & & \\
4 & 0.81 & 16.11 & 96.04 & & & \\
5 & 0.19 & 3.96 & 100.00 & & & \\
\hline
\end{tabular}

\begin{tabular}{lcc}
\hline Element & \multicolumn{2}{c}{ Component matrix } \\
\cline { 2 - 3 } & PC1* & PC2* \\
\hline $\mathrm{Cu}$ & 0.88 & -0.10 \\
$\mathrm{~Pb}$ & 0.58 & 0.14 \\
$\mathrm{Ni}$ & 0.00 & 0.74 \\
$\mathrm{Cd}$ & -0.07 & -0.71 \\
$\mathrm{Zn}$ & 0.93 & 0.05 \\
\hline
\end{tabular}

*PC1-Principal component one, PC2-Principal component 2

According to the correlation analysis, $\mathrm{Cu}$ and $\mathrm{Zn}$ must have a similar origin as both are highly correlated among them in all three land uses. In PCA, $\mathrm{Cu}, \mathrm{Zn}$ and $\mathrm{Pb}$ were clustered into a single group. Therefore, it can be stated that $\mathrm{Cu}, \mathrm{Zn}$ and $\mathrm{Pb}$ could possibly be originated from a mixed source i.e., anthropogenic and natural sources. Copper could enter through $\mathrm{Cu}$ containing fungicides as anthropogenic sources. Anthropogenic source of $\mathrm{Zn}$ may be the $\mathrm{Zn}$ fertilizers and $\mathrm{Zn}$ containing minerals. Lead also originates from anthropogenic as well as natural sources. 


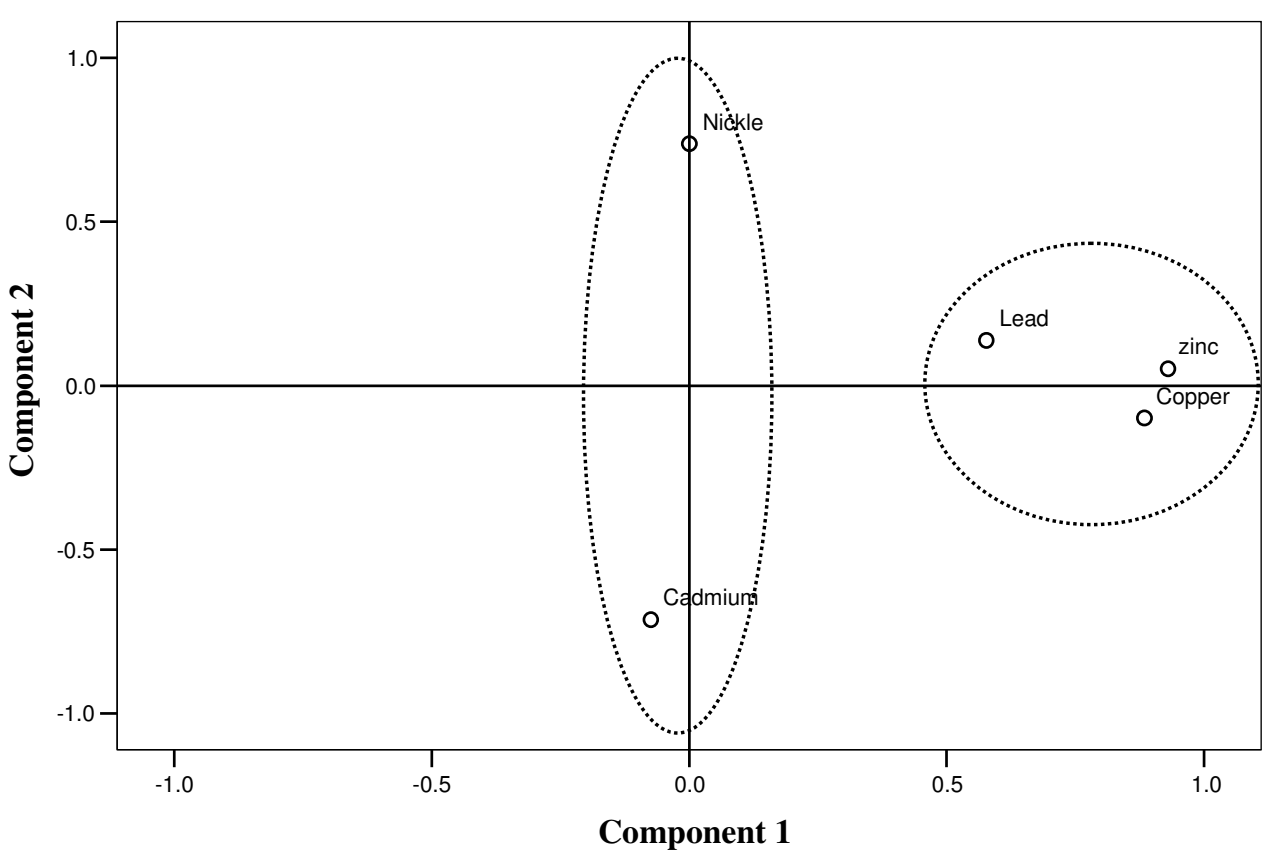

Fig. 2. Principal component analysis loading plot for the two rotated components

The observed concentrations of Cd were higher than the background value of $0.37 \mathrm{mg} \mathrm{kg}^{-1}$ reported by Kabata-Pendias (1992) for world soils. Therefore, the source of Cd has an anthropogenic origin. Positive relationships between $\mathrm{Ni}$ and $\mathrm{Cu}, \mathrm{Zn}, \mathrm{Pb}$ implied that $\mathrm{Ni}$ has a geogenic origin. In PCA analysis, $\mathrm{Cd}$ and $\mathrm{Ni}$ have been grouped into a same cluster but with a positive factor loading on Ni. Therefore, Ni could origin from natural source. However, it is difficult to conclude that sources of trace metals without analyzing soil properties. Because adsorption and retention of trace metals in soils are influenced by several factors such as organic matter, clay minerals, carbonates (Mico et al., 2006) and cation exchange capacity (Aydinalp \& Marinova, 2003). Lithogenic metals highly correlate with soil properties (Ma et al., 1997) whereas anthropogenic metals have a weaker relationship with soil properties (Mico et al., 2006). Therefore, further analysis has to be investigated to identify the sources of trace metals.

\section{CONCLUSION}

An assessment of the environmental risk due to environmental pollution such as trace metals is important for agricultural and non-agricultural areas. The present study revealed that both agricultural and non-agricultural soils of the studied catena were not contaminated to an environmental risk level for $\mathrm{Cd}, \mathrm{Cu}, \mathrm{Pb}, \mathrm{Ni}$ and $\mathrm{Zn}$. Observed total concentrations of $\mathrm{Cd}, \mathrm{Cu}$, $\mathrm{Pb}, \mathrm{Ni}$ and $\mathrm{Zn}$ of the catena are below the maximum permissible limits reported in the literature. Land uses influence the trace metal concentrations of $\mathrm{Cd}, \mathrm{Pb}$ and $\mathrm{Zn}$ whereas $\mathrm{Cu}$ and $\mathrm{Ni}$ concentrations are not different with different land uses. Copper shows positive relationships with $\mathrm{Pb}, \mathrm{Zn}$ and $\mathrm{Ni}$ and $\mathrm{Pb}$ shows positive relationship with $\mathrm{Ni}$ in paddy cultivated soils. Copper shows positive relationships with $\mathrm{Ni}$ and Zn. Zinc also shows the 
relationship with $\mathrm{Ni}$ in vegetable growing lands. Based on the principal component and factor analysis $\mathrm{Cu}, \mathrm{Zn}$ and $\mathrm{Pb}$ could have been originated from mixed component of natural and antropogenic sources and $\mathrm{Cd}$ possibly enters in to the soils through only anthropogenic sources. Nickel could enter from natural parent materials.

\section{ACKNOWLEDGEMENT}

National Research Council grants number NRC 11_166 is acknowledged for their financial support for this research. Head and the technical staff of the Departments of Soil Science and Food Science and Technology, Faculty of Agriculture, University of Peradeniya are highly acknowledge for technical and analytical support extended during the study.

\section{REFERENCES}

Aydinalp, C. and Marinova, S. (2003). Distribution and forms of heavy metals in some agricultural soils.Polish Journal of Environmental Studies.12, 629 - 633.

Bandara, J.M.R.S., Senevirathna, D.M.A.N., Dasanayake, D.M.R.S.B., Herath, V., Bandara, J.M.R.P. Abeysekara, T., and Rajapaksha, K.H. (2008). Chronic renal failure among farm families in cascade irrigation systems in Sri Lanka associated with elevated dietary cadmium levels in rice and freshwater fish (Tilapia). Environment Geochemistry and Health.30, 465 478.

Bandara, W.M.J., Kumaragamage, D., Wichramasinghe, D.B. and Weerawarna, S.B.A. (2005).Site Specific Nutrient Management Strategy to Increase Rice Yields in Low Country Intermediate Zone.Journal of Soil Science Society Sri Lanka.17, 32 - 43.

Budiman, M. and McBratney, A.B. (2006). A conditioned latin hypercube method for sampling in the presence of ancillary information. Computers and Geosciences 32, 1378 1388.

Burt, R., Wilson, M.A., Mays, M.D. and Lee, C.W. (2003). Major and trace elements of selected pedon in the USA.Journal of Environmental Quality. 32, 2109 - 2121.

Chandrajith, R., Nanayakkara, S., Itai, K., Athuraliya, T.N.C., Dissanayake, C.B., Abysekara, T., Harada, K., Wtanabe, T. and Koizumi, A. (2010). Chronic kidney diseases of uncertain etiology in Sri Lanka: geographic distribution and environmental implications. Environment Geochemistry and Health.85-96.

Cobb, G.B., Sands, K., Waters, M., Wixson, B.G. and Dowrward-King, E. (2000). Accumulation of heavy metals by vegetables grown in mine waste.Environmental Toxicology Chemistry.19, 600 - 607.

Davies, J.A. (1984). Complexation of trace metals by adsorbed natural organic matter. Geochim.Cosmochim.Acta.48, 679 - 691.

Dissanayake, C.B. and Chandrajith, R. (2009). Phosphate mineral fertilizers, trace metals and human health. Journal of the National Science Foundation.37, 153 - 165. 
He, Z.L., Zhang, M.K., Calvert, D.V., Stoffella, P.J., Yang, X.E. and Yu.S.(2004). Transport of heavy metals in surface runoff from vegetable and citrus fields.Journal of Soil Science Society America.68, 1662 - 1669.

Indraratne, S.P.,Vitharana,U.W.A., Rajapaksha, R.M.C.P., Dias, K.M.G.D.N., Weerasooriya, R. and Sajeewani, U.K.P.S. (2011). Assessment of Phosphate and Cadmium levels in Water resources in dry zone of Sri Lanka: A case study. The $10^{\text {th }}$ international conference of the East and South-East Asia federation of Soil Science societies.325-326pp.

Jayawardena, D.T., Pitawala, H.M.T.G.A. and Ishiga, H. (2012). Geochemical assessment of Arsenic and selected trace elements in Agricultural and non-agricultural soils of Sri Lanka.Tropical Agriculturist.160, 1 - 19.

Kabata-Pendias, A., Dedka, A. and Chlopecka, A. (1992). Background levels and environmental influence on trace metals in soils of the temperate humid zone of Europe. pp. 61-84. In: D.C.Adriance (Ed).Biogeochemistry of trace metals. CRC Press; Boca Ratom, FL.

Li, J., Lu, Y., Yin, W., Gan, H., Zhang, C. and Dang, X. (2009). Distribution of heavy metals in agricultural soils near a petrochemical complex in Guangzhou, China.Environment Monitoring andAssessment.153, 365375.

Liu, G.D. (2001). A new essential mineral element- Nickel.Plant Nutrition and Fertilizer Science.7, $101-103$.

Liu, G.D., Simonne, E.H. and Li, Y. (2011). Nickel nutrition in plants. Horticultural Sciences, Florida cooperative extension service, Institute of Food and Agricultural sciences, University of Florida .pp 1-5.

Lu, Y., Lue, W., Giesy, E.J.P., Wang, E.T., Shi, E.Y., Wang, E.G. and Xing, E.Y. (2007).Effect of land use on concentrations of metals in surface soils and ecological risks around Guanting reservoirs, China.Environmental Geochemistry and Health.29, 459 - 471.

Ma, L.Q., Tan, F., Harris, W.G. (1997). Concentrations and distributions of eleven metals in Florida soils. Journal of Environmental Quality.26, 769-775.

Mapa, R.B. (2010). Introduction. Pp.1-6. In: Mapa.R.B.,Somasiri.S. andDassanayake. A.R. (Ed.) Soils of Dry Zone of Sri Lanka.Soil Science Society of Sri Lanka., Peradeniya, Sri Lanka.

McGrath, D. and McCormack, R.J. (1999).The significance of heavy metal and 28 organic micro pollutants in soils. Rural Environ.Ser.23.Johnstown castle resource 29 center, Wexford, Ireland:278p.

McGrath, S.P. (1995). Nickel.In Heavy metals in soils. ( $2^{\text {nd }}$ Edn). B.J. Alloway,.London, Blackie Academic and Professional.

Mico, C., Recatala, L., Peris, M. and Sanchez, J. (2006). Assessing heavy metal sources in agricultural soils of an European Mediterranean area by multivariate analysis. Chemosphere.65, 863-872. 
Pierzynski, G.M., Sims, J.T. and Vance, F. (2000). Soils and environmental quality. ${ }^{\text {nd }}$ Ed. CRC Press.LLC. 243pp.

Premarathne, H.M.P.L., Hettiarachchi, G.M. and Indraratne, S.P. (2011). Trace metal concentration in crops and soils collected from intensively cultivated areas of Sri Lanka. Pedologist.230-240.

Premarathne, H.M.P.L., Hettiarachchi, G.M. and Indraratne, S.P. (2005). Accumulation of Cadmium in intensive vegetable growing soils in the Upcountry. Tropical Agricultural Research, 17, 93 - 103.

Rezania, M., Yogarathnum, V. and Wijewardena, J.D.H. (1989). Fertilizer use on potato in relation to soil productivity in the upcountry areas of Sri Lanka.FAO, Rome. Field document no. 3,35 .

Rudnick, R.L. and Gao, S. (2005). Composition of the continental crust.In Treatise in geochemistry.3, 1 - 44 .

Sanjeevani, U.K.P.S., Indraratne, S.P., Weerasooriya, S.V.R. and Vitharana, W.U.A. (2012). Trace element baseline concentration in a selected soil map unit of Sri Lanka. Proceedings of Peradeniya University Research Session, $4^{\text {th }}$ July, 2013. University of Peradeniya.17: pp 230.

Sposito, G., Levesque, C.S., Leclaire, J.P and Chang, A.C. (1983). Trace metal chemistry in arid zone field soil amended with sewage sludge. III. Effect of time on the extraction of trace metals. Journal of Soil Science Society of America.47, 898 - 902.

Wanigasuriya, K.P., Peries, H. and Illeperuma, N. (2008). Could ochratoxinA in food commodities be the cause of chronic kidney disease in Sri Lanka? Transactions of the Royal Society of Tropical Medicine and Hygiene.102, 726 - 728.

Wijewardena, J.D.H. and Gunaratne, S.P. (2004). Heavy metal contents in commonly used animal manure. Annals of the Sri Lanka Department of Agriculture.6, 245 - 253.

Xing, B. and Veneman, P.L.M. (1998).Microwave digestion for analysis of metals in soils.Communications in Soil Science and Plant Analysis.29, 923 - 930. 